\title{
Dynamic Antibody Responses in Patients with Different Severity of COVID-19: A Retrospective Study
}

Wanrong $\mathrm{Lu} \cdot$ Ping $\mathrm{Wu} \cdot$ Liang $\mathrm{He} \cdot$ Yifan Meng $\cdot$ Peng $\mathrm{Wu} \cdot$

Wencheng Ding $\cdot$ Jia Liu (D)

Received: January 5, 2021 / Accepted: February 23, 2021 / Published online: May 29, 2021

(c) The Author(s) 2021

\begin{abstract}
Introduction: The coronavirus disease 2019 (COVID-19) pandemic is a serious public health event and poses a global health threat. To study the specific antibody responses would contribute to a better understanding of COVID-19. Methods: We collected complete follow-up data from 777 patients with pathogen-confirmed COVID-19 with corresponding immunoglobulin $\mathrm{G}$ and $\mathrm{M}$ (IgG/IgM) testing results.
\end{abstract}

Results: Overall, the positive rates of IgG and IgM in severe patients were slightly higher than

Wanrong Lu and Ping Wu contributed equally to this work.

W. Lu · P. Wu · L. He · P. Wu · W. Ding · J. Liu ( $₫)$ Cancer Biology Research Center (Key Laboratory of the Ministry of Education), Tongji Hospital, Tongji Medical College, Huazhong University of Science and Technology, Wuhan, China

e-mail: whgoy3k@163.com

W. Lu · L. He · P. Wu · W. Ding · J. Liu Department of Gynecologic Oncology, Tongji Hospital, Tongji Medical College, Huazhong University of Science and Technology, Wuhan, China

Y. Meng

Department of Gynecologic Oncology, State Key Laboratory of Oncology in South China, Collaborative Innovation Center for Cancer Medicine, Sun Yat-Sen University Cancer Center, Guangzhou, China those in non-severe patients. In addition, higher IgG levels were detected in severe patients compared to non-severe patients $(P=0.026)$. Through further analysis, differences in IgG were only significant in serum samples taken in the first 14 days of disease onset $(P<0.001)$. On the basis of analysis of antibody expression levels at different time points in 74 patients who had undergone more than three detection tests, we found that the differences in IgG levels between the severe/ non-severe patients were more pronounced than those of IgM. On multivariate logistic regression, after adjusting for cofactors, the higher anti-SARS-CoV-2 (severe acute respiratory syndrome coronavirus 2) IgG levels observed in the first 14 days of disease onset were independently associated with severe COVID-19 disease (odds ratio $(\mathrm{OR})=1.368$, 95\% confidence interval (CI) 1.138-1.645).

Conclusion: We observed differences in antibody responses among patients with different severity of COVID-19. A high IgG level in the first 14 days of disease may be positively associated with disease severity.

Keywords: COVID-19; Immunoglobulin G (IgG); Immunoglobulin M (IgM); SARS-CoV-2 


\section{Key Summary Points}

\section{Why carry out this study?}

To date, there are more than $80,000,000$ SARS-Cov-2-infected patients and global health systems face challenges against COVID-19.

We speculate that the level of specific antibodies may be related to the severity of the COVID-19.

\section{What was learned from the study?}

The virus-specific IgG against SARS-Cov-2 might be tested seropositive at the same time or earlier than virus-specific IgM.

There were differences in specific antibody immune response in patients with different severity of COVID-19. A strong specific IgG response in the early stage of disease (within 14 days from disease onset) might be associated with severe COVID-19.

\section{DIGITAL FEATURES}

This article is published with digital features, including a summary slide, to facilitate understanding of the article. To view digital features for this article go to https://doi.org/10.6084/ m9.figshare.14095683.

\section{INTRODUCTION}

Severe acute respiratory syndrome coronavirus 2 (SARS-CoV-2) has rapidly spread worldwide, with more than 80 million people infected as of 4 January 2021. At present, virusspecific immunoglobulin $\mathrm{G}$ (IgG) and immunoglobulin $\mathrm{M}$ ( $\operatorname{IgM}$ ) antibody detection tests are used to predict population immunity against coronavirus disease 2019 (COVID-19) and to screen severe acute respiratory syndrome coronavirus 2

(SARS-CoV-2)-infected

populations. These tests are also critical for patients with undetectable viral loads that are below the lower limit of reverse transcriptase polymerase chain reaction (RT-PCR) assays [1-3].

On the basis of current data, approximately $80 \%$ of patients with COVID-19 are considered non-severe. However, for those patients that progress to severe/critical disease, mortality rates increase significantly [4, 5]. As such, potential indicators that can help predict disease progression will have great significance in clinical practice. Previous studies have indicated that the immune response differs between severe and non-severe patients $[6,7]$. Therefore, we speculated that differences in immune response may also affect the expression of specific antibodies. At present, however, whether the levels of anti-SARS-CoV-2 antibodies are associated with COVID-19 progression and prognosis remains unclear, and clinical studies remain controversial. For example, Phipps et al. reported that antibody responses were ineffectual at predicting disease progression [8]. In contrast, Liu et al. found that serum IgM titer changes as COVID-19 progresses, and high levels of IgM are associated with acute respiratory distress syndrome (ARDS) in severe/critical patients [9].

In the current study, we aimed to explore the associations between dynamic antibody responses and clinical disease severity in patients with COVID-19. We included 777 patients with pathogen-confirmed COVID-19 and analyzed their SARS-CoV-2 antibody tests. We found that the IgG level in severe patients was significantly higher than that in non-severe patients in the first 14 days after symptom onset; however, this association was not obvious after 14 days. Therefore, our study suggests that early antibody response may be related to COVID-19 prognosis.

\section{METHODS}

\section{Study Design and Participants}

In total, 777 hospitalized patients with COVID19 at Tongji Hospital in Wuhan, China, from 18 January to 26 April 2020 were included in this 
study. All patients had pathogen-confirmed COVID-19 and consented to serological-specific antibody detection tests. SARS-CoV-2 infection was confirmed by RT-PCR, as previous study [10].

All patients (100\%, 777/777) with complete follow-up data reached the endpoints of observation (i.e., discharged or died at hospital). Clinical and demographic data on the confirmed cases were collected from their medical records. Severe COVID-19 cases were defined as those with oxygen saturation of $94 \%$ or less while breathing ambient air or needing oxygen support, consistent with Ohmagari et al. [11]. The Ethical Committee of Tongji Hospital approved the study. All procedures were conducted in accordance with ethical standards in the 1964 Helsinki declaration and its later amendments or comparable ethical standards. All data were analyzed anonymously. As a result of the retrospective nature of the study, informed consent was waived.

\section{Detection of Antibodies Against SARS- CoV-2}

The SARS-CoV-2 IgM and IgG antibody tests were conducted using YHLO-CLIA-IgM and YHLO-CLIA-IgG kits (YHLO Biotech Co., Ltd., Shenzhen, China) in accordance with the provided instructions, and the samples for IgM/IgG antibody tests were drawn at the same time for each individual patient. Antibody expression was measured in arbitrary units (AU) per milliliter. Positive and negative results for both IgM and IgG were indicated by greater than $10 \mathrm{AU} /$ $\mathrm{mL}$ and $10 \mathrm{AU} / \mathrm{mL}$ or less, respectively. For each patient, we calculated the interval time between the time from disease onset and date of $\operatorname{IgG} / \mathrm{IgM}$ tests. The detection method for antibodies against SARS-CoV-2 was consistent with previous research [12]. All serum samples were dated from the day of symptom onset.

\section{Statistical Analysis}

All analyses were conducted with SAS v9.4 (SAS Inc.). Measurement data were expressed as the mean and standard deviation (SD) or median and interquartile range (IQR). Comparisons among two or three different groups were performed by $t$ tests or $F$ tests when the measurement data were normally distributed. Otherwise, Mann-Whitney $U$ or Kruskal-Wallis tests were applied. Enumeration data were summarized as frequency rates and percentages. Intergroup comparisons of enumeration data were performed using chi-squared tests. Logistic analysis was used to explore the influence of the log-transformed level of IgG at different sampling times from disease onset on the risk of non-severe or severe. $P<0.05$ was considered statistically significant.

\section{RESULTS}

We performed a retrospective analysis of 777 patients with SARS-CoV-2 infection. According to disease severity, patients were categorized into severe $(417 / 777,53.7 \%)$ and non-severe groups (360/777, 46.3\%). The median (IQR) days from disease onset to $\operatorname{IgG} / \operatorname{IgM}$ detection for the severe patients, non-severe patients, and total patients were 13.0 (8.0-20.0) days, 25.0 (10.0-38.5) days, and 15.0 (9.0-31.0) days, respectively. Table 1 illustrates the baseline characteristics of the 777 patients with COVID19. The mean age of the cohort was 58.1 years. The proportions of male to female patients did not differ significantly between the two groups. Patients in the severe group $(62.2 \pm 13.8$ years $)$ were significantly older than those in the nonsevere group (53.5 \pm 16.7 years). The most common comorbidity was hypertension $(31.2 \%)$, which was also the only comorbidity that showed significant differences in prevalence between the two groups. Diabetes (15.6\%) and coronary heart disease $(6.3 \%)$ were also common comorbidities in patients. The most common symptoms in more than half of patients were fever $(67.8 \%)$, cough $(54.8 \%)$, and expectoration (40.5\%). Results indicated that symptoms with significantly different distributions among the $(P<0.05)$, such as fever, cough, and dyspnea, were more common in severe patients than in non-severe patients. All patients reached the observation endpoints by 26 April 2020, and the clinical outcomes are 
Table 1 Baseline characteristics of 777 patients with COVID-19

\begin{tabular}{|c|c|c|c|c|}
\hline & $\begin{array}{l}\text { Non-severe } \\
(n=360)\end{array}$ & $\begin{array}{l}\text { Severe } \\
(n=417)\end{array}$ & $\begin{array}{l}\text { Total } \\
(n=777)\end{array}$ & $P^{\mathbf{a}}$ \\
\hline $\operatorname{Sex}(n[\%])$ & & & & 0.15 \\
\hline Male & $168(46.7)$ & $216(51.8)$ & $384(49.4)$ & \\
\hline Female & $192(53.3)$ & $201(48.2)$ & $393(50.6)$ & \\
\hline Age (years, mean $[S D]$ ) & $53.5(16.7)$ & $62.2(13.8)$ & $58.1(15.9)$ & $<0.0001$ \\
\hline \multicolumn{5}{|l|}{ Comorbidities $(n[\%])$} \\
\hline Hypertension & $83(23.1)$ & $159(38.1)$ & $242(31.2)$ & $<0.0001$ \\
\hline Coronary heart disease & $17(4.7)$ & $32(7.7)$ & $49(6.3)$ & 0.091 \\
\hline Diabetes & $46(12.8)$ & $75(18.0)$ & $121(15.6)$ & 0.046 \\
\hline Chronic obstructive pulmonary disease & $6(1.7)$ & $6(1.4)$ & $12(1.5)$ & 0.80 \\
\hline Chronic kidney disease & $2(0.6)$ & $4(1.0)$ & $6(0.8)$ & 0.69 \\
\hline Cerebrovascular disease & $15(4.2)$ & $21(5.0)$ & $36(4.6)$ & 0.57 \\
\hline Hepatitis & $5(1.4)$ & $8(1.9)$ & $13(1.7)$ & 0.57 \\
\hline Tuberculosis & $7(1.9)$ & $10(2.4)$ & $17(2.2)$ & 0.67 \\
\hline Tumor & $15(4.2)$ & $15(3.6)$ & $30(3.9)$ & 0.68 \\
\hline \multicolumn{5}{|l|}{ Signs and symptoms $(n[\%])$} \\
\hline Fever & $222(61.7)$ & $305(73.1)$ & $527(67.8)$ & 0.0006 \\
\hline Fatigue & $47(13.1)$ & $74(17.8)$ & $121(15.6)$ & 0.072 \\
\hline Cough & $177(49.2)$ & $249(59.7)$ & $426(54.8)$ & 0.0032 \\
\hline Expectoration & $146(40.6)$ & $169(40.5)$ & $315(40.5)$ & 0.99 \\
\hline Dyspnea & 77 (21.4) & $167(40.1)$ & $244(31.4)$ & $<0.0001$ \\
\hline Headache & $6(1.7)$ & $18(4.3)$ & $24(3.1)$ & 0.033 \\
\hline Dizziness & $21(5.8)$ & $18(4.3)$ & $39(5.0)$ & 0.33 \\
\hline Diarrhea & $69(19.2)$ & 78 (18.7) & $147(18.9)$ & 0.87 \\
\hline Thoracodynia & $55(15.3)$ & $66(15.8)$ & $121(15.6)$ & 0.83 \\
\hline Nausea & $13(3.6)$ & $26(6.2)$ & $39(5.0)$ & 0.095 \\
\hline Myalgia & $29(8.1)$ & $38(9.1)$ & $67(8.6)$ & 0.60 \\
\hline Chills & $29(8.1)$ & $45(10.8)$ & $74(9.5)$ & 0.20 \\
\hline Pharyngalgia & $20(5.6)$ & $16(3.8)$ & $36(4.6)$ & 0.26 \\
\hline Vomiting & $7(1.9)$ & $11(2.6)$ & $18(2.3)$ & 0.52 \\
\hline Abdominal pain & $5(1.4)$ & $4(1.0)$ & $9(1.2)$ & 0.74 \\
\hline
\end{tabular}


Table 1 continued

\begin{tabular}{lcccc}
\hline & $\begin{array}{l}\text { Non-severe } \\
(\boldsymbol{n}=\mathbf{3 6 0})\end{array}$ & $\begin{array}{l}\text { Severe } \\
(\boldsymbol{n}=\mathbf{4 1 7})\end{array}$ & $\begin{array}{l}\text { Total } \\
(\boldsymbol{n}=777)\end{array}$ & $\boldsymbol{P}^{\mathbf{a}}$ \\
\hline Prognosis & & & $736(94.7)$ & $<0.0001$ \\
Recovered & $360(100.0)$ & $376(90.2)$ & $41(5.3)$ & $<0.0001$ \\
Death & $0(0.0)$ & $41(9.8)$ & \\
\hline
\end{tabular}

${ }^{a} P$ values comparing different groups are from $\chi^{2}$ test, $t$ test, or the Mann-Whitney $U$ test
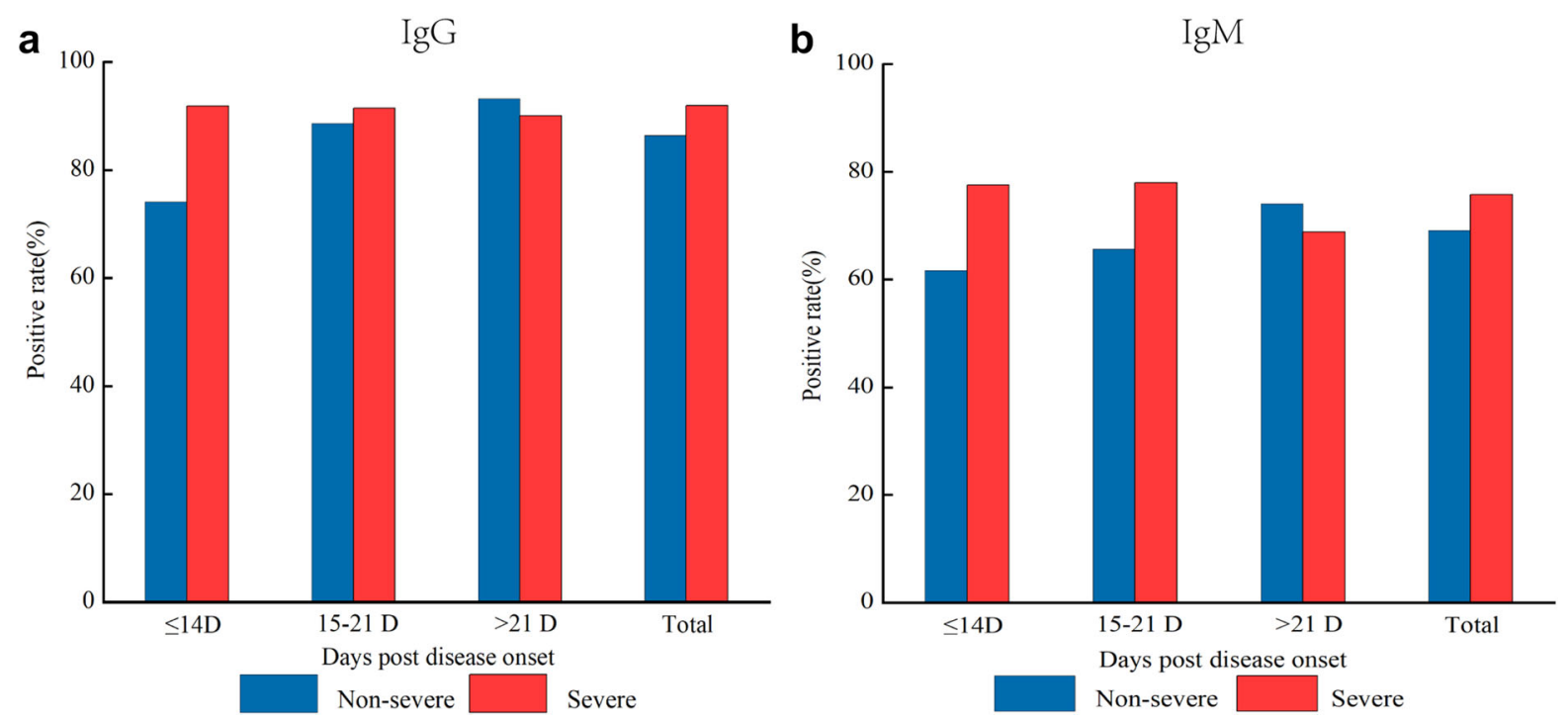

Fig. 1 Positive rates of SARS-CoV-2-specific antibodies during different disease progression periods. a IgG and $\mathbf{b} \operatorname{IgM}$

summarized in Table 1. In total, 5.3\% (41/777) of patients died and $94.7 \%$ (741/777) of patients were discharged. All deceased patients were severe cases.

As shown in Fig. 1, dynamic changes were found in the positive rates of IgG and IgM in severe/non-severe patients. In the first 14 days from the onset of symptoms, the positive rate of IgG was significantly higher in severe patients $(91.8 \%)$ than in non-severe patients $(74.2 \%$, Fig. 1a), with the same trend observed for IgM $(77.6 \%$ and $61.7 \%$, respectively, Fig. $1 b)$. In addition, the higher positive rate of IgM in severe patients remained for 15-21 days. After 21 days, the positive rates of IgG and IgM were similar between the two groups. Furthermore, the positive rate of IgG persisted at a relatively high level (greater than 90\%) in severe patients for the duration of the study. However, the positive rate of $\operatorname{IgG}$ in non-severe patients exhibited an obvious increase, reaching a peak of $93.2 \%$ after 21 days.

To further explore the characteristics of patient immune response to SARS-CoV-2 infection, we analyzed the correlations among levels of specific antibodies and clinical progression. The average levels of IgG and IgM in patients with COVID-19 are shown in Fig. $2 a, b$. The level of IgG was significantly higher in severe patients than in non-severe patients. However, there was no difference in the average level of IgM between the two groups. As a result of the changes in positive antibody rates over time, we suspected that antibody levels may be time dependent. The average levels of IgG and IgM from symptom onset to the first detection of corresponding antibodies are shown in Fig. 2c, d. During the first 2 weeks from disease onset, 

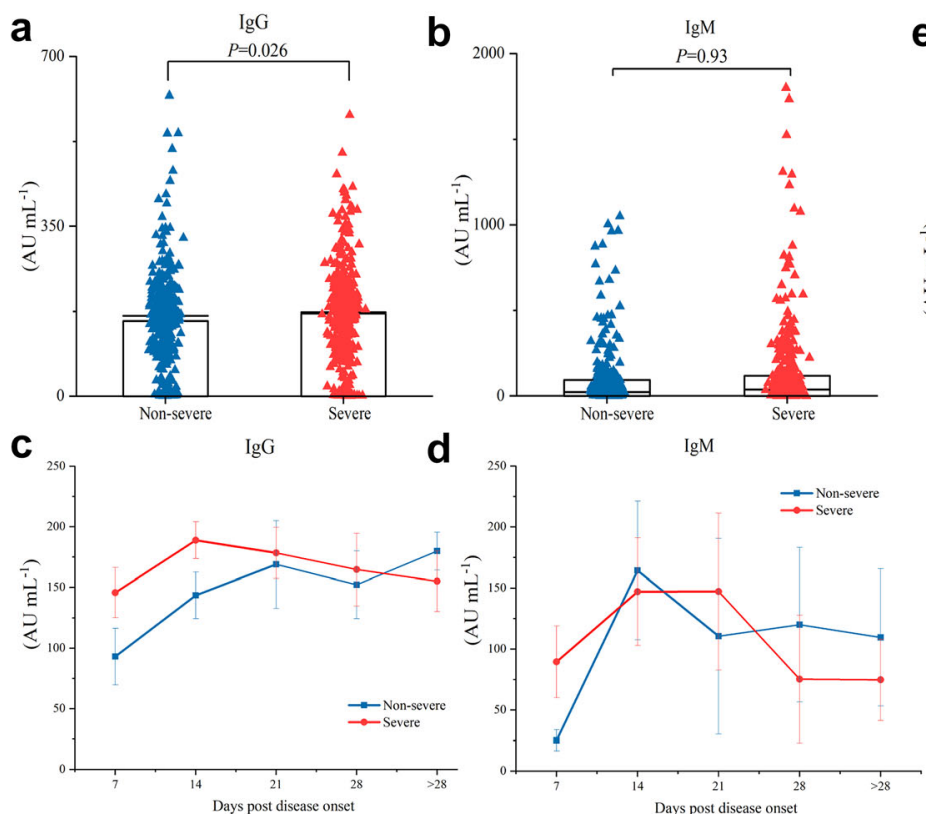

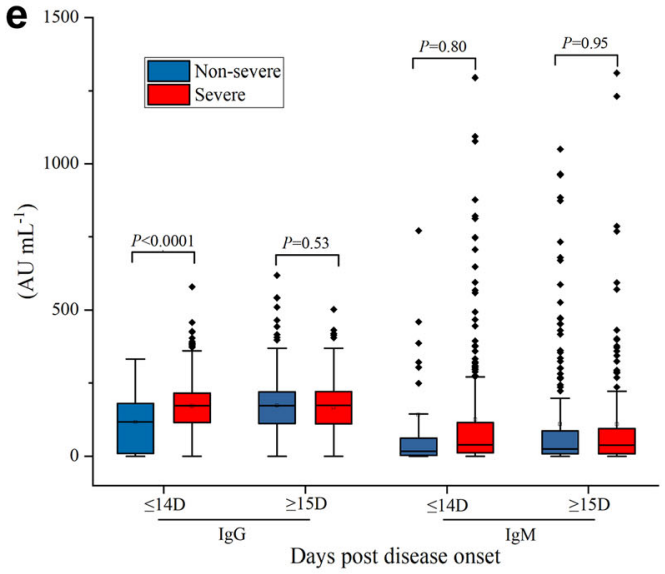

disease progression periods. Comparison of specific $\operatorname{IgG}$ and IgM levels in patients with different severity of COVID-19 (e)

groups (Table 2). However, significant differences between the normal/abnormal-range groups became more pronounced in IgM. Of note, lymphocyte count $(P=0.0010)$, D-dimer $(P=0.019)$, ferritin $(P=0.021)$, alanine aminotransferase $(P=0.036)$, aspartate aminotransferase $(P=0.012)$, albumin $(P=0.0020)$, high sensitivity C-reactive protein $(P=0.0091)$, and tumor necrosis factor alpha $(P=0.0069)$ differed significantly among the various groups.

To investigate the dynamic changes in IgG and IgM within each individual patient during disease progression, we screened 74 cases where patients underwent serological-specific antibody detection at least three times. T1 represents the first test after admission, T2 represents the test closest to the midpoint of hospitalization, and T3 represents the last test before discharge. We observed that the levels of IgG and IgM showed downward trends. At all three time points, the average levels of IgG and IgM were higher in severe patients than in non-severe patients. In addition, the difference was more pronounced for IgG than for IgM, especially at $\mathrm{T} 1$ and T2. The levels of IgM between the 
Table 2 Comparison of anti-SARS-CoV-2 IgG and IgM among different laboratory parameter groups

\begin{tabular}{|c|c|c|c|c|}
\hline Laboratory parameters (normal range) & IgG & $P^{\mathbf{a}}$ & IgM & $P^{\mathbf{a}}$ \\
\hline $\begin{array}{l}\text { White blood cell count }\left(\times 10^{9} / \mathrm{L} \text {, median }[\mathrm{IQR}]\right) \\
(3.5-9.5)\end{array}$ & & 0.50 & & 0.23 \\
\hline$<3.5$ & $154.9(93.1-194.3)$ & & $42.0(13.2-138.9)$ & \\
\hline $3.5-9.5$ & $171.6(105.9-211.2)$ & & $29.3(8.8-87.5)$ & \\
\hline$>9.5$ & $166.1(85.8-233.7)$ & & $32.9(5.8-143.3)$ & \\
\hline Neutrophil count $\left(\times 10^{9} / \mathrm{L}\right.$, median $\left.[\mathrm{IQR}]\right)(1.8-6.3)$ & & 0.72 & & 0.41 \\
\hline$<1.8$ & $167.0(89.3-221.9)$ & & $25.5(10.3-109.6)$ & \\
\hline $1.8-6.3$ & $170.0(106.4-207.8)$ & & $29.1(8.6-88.3)$ & \\
\hline$>6.3$ & $172.1(92.0-232.6)$ & & $36.6(7.8-136.1)$ & \\
\hline Lymphocyte count $\left(\times 10^{9} / \mathrm{L}\right.$, median $\left.[\mathrm{IQR}]\right)(1.1-3.2)$ & & 0.37 & & 0.0010 \\
\hline$<1.1$ & $171.8(104.9-215.2)$ & & $42.8(11.1-117.6)$ & \\
\hline$\geq 1.1$ & $167.0(101.4-210.8)$ & & $25.0(7.5-75.7)$ & \\
\hline Monocyte count $\left(\times 10^{9} / \mathrm{L}\right.$, median $\left.[\mathrm{IQR}]\right)(0.1-0.6)$ & & 0.12 & & 0.22 \\
\hline$<0.6$ & $172.4(107.4-212.6)$ & & $33.7(9.1-94.9)$ & \\
\hline$\geq 0.6$ & $160.8(90.1-207.0)$ & & $25.5(5.8-93.7)$ & \\
\hline D-Dimer $(\mu \mathrm{g} / \mathrm{ml}$, median $[\mathrm{IQR}])(<0.5)$ & & 0.17 & & 0.019 \\
\hline$<0.5$ & $163.7(93.1-203.0)$ & & $24.6(6.4-72.0)$ & \\
\hline$\geq 0.5$ & $170.0(104.8-212.6)$ & & $35.4(8.5-107.0)$ & \\
\hline Ferritin $(\mu \mathrm{g} / \mathrm{L}$, median $[\mathrm{IQR}])(30-400)$ & & 0.69 & & 0.021 \\
\hline$\leq 400$ & $176.4(111.9-219.2)$ & & $28.3(9.0-75.4)$ & \\
\hline$>400$ & $171.0(117.4-210.3)$ & & $39.9(12.6-115.4)$ & \\
\hline Alanine aminotransferase $(\mathrm{U} / \mathrm{L}$, median $[\mathrm{IQR}])(\leq 41)$ & & 0.69 & & 0.036 \\
\hline$\leq 41$ & $172.3(104.4-212.5)$ & & $28.1(7.9-90.0)$ & \\
\hline$>41$ & $171.0(128.9-204.5)$ & & $35.4(15.9-129.8)$ & \\
\hline Aspartate aminotransferase $(\mathrm{U} / \mathrm{L}$, median $[\mathrm{IQR}])(\leq 40)$ & & 0.55 & & 0.012 \\
\hline$\leq 40$ & $171.6(105.5-212.5)$ & & $27.3(7.9-78.9)$ & \\
\hline$>40$ & $171.5(125.9-206.0)$ & & $43.9(13.9-132.0)$ & \\
\hline Albumin $(\mathrm{g} / \mathrm{L}$, median $[\mathrm{IQR}])(35-52)$ & & 0.049 & & 0.0020 \\
\hline$<35$ & $177.7(125.0-213.0)$ & & $41.6(13.2-111.9)$ & \\
\hline$\geq 35$ & $168.3(102.4-211.9)$ & & $23.9(7.8-75.3)$ & \\
\hline Total bilirubin $(\mu \mathrm{mol} / \mathrm{L}$, median $[\mathrm{IQR}])(\leq 26)$ & & 0.0092 & & 0.10 \\
\hline$\leq 26$ & $172.4(111.2-212.5)$ & & $30.8(9.1-93.7)$ & \\
\hline$>26$ & $9.9(2.2-159.1)$ & & $4.1(0.9-119.7)$ & \\
\hline
\end{tabular}


Table 2 continued

\begin{tabular}{|c|c|c|c|c|}
\hline Laboratory parameters (normal range) & IgG & $P^{\mathbf{a}}$ & IgM & $P^{\mathbf{a}}$ \\
\hline $\begin{array}{l}\text { High sensitivity C-reactive protein }(\mathrm{mg} / \mathrm{L} \text {, median }[\mathrm{IQR}]) \\
(<1)\end{array}$ & & 0.52 & & 0.0091 \\
\hline$<1$ & $166.3(96.2-211.9)$ & & $22.3(4.9-61.1)$ & \\
\hline$\geq 1$ & $169.7(104.0-212.5)$ & & $34.6(9.8-101.0)$ & \\
\hline Procalcitonin $(\mathrm{ng} / \mathrm{mL}$, median $[\mathrm{IQR}])(0.02-0.05)$ & & $<0.0001$ & & 0.21 \\
\hline$<0.05$ & $182.0(135.4-222.0)$ & & $32.9(11.6-94.5)$ & \\
\hline$\geq 0.05$ & $162.9(89.3-202.3)$ & & $30.8(6.1-94.5)$ & \\
\hline Complement $3(\mathrm{~g} / \mathrm{L}$, median $[\mathrm{IQR}])(0.65-1.39)$ & & 0.75 & & 0.25 \\
\hline$<0.65$ & $169.1(99.2-214.4)$ & & $26.7(7.9-91.3)$ & \\
\hline $0.65-1.39$ & $171.0(108.3-208.0)$ & & $36.0(9.1-96.8)$ & \\
\hline$>1.39$ & $189.3(176.4-202.3)$ & & $51.9(38.1-65.6)$ & \\
\hline Complement 4 (g/L, median [IQR]) (0.16-0.38) & & 0.98 & & 0.18 \\
\hline$<0.16$ & $169.2(101.0-214.4)$ & & $28.0(7.9-88.2)$ & \\
\hline $0.16-0.38$ & $170.4(108.3-206.8)$ & & $34.8(9.1-102.5)$ & \\
\hline$>0.38$ & $163.5(122.3-198.9)$ & & $67.2(14.0-334.0)$ & \\
\hline Interleukin-2 receptor $(\mathrm{U} / \mathrm{mL}$, median $[\mathrm{IQR}])(223-710)$ & & 0.78 & & 0.82 \\
\hline$<710$ & $171.3(101.3-215.0)$ & & $30.5(8.9-91.3)$ & \\
\hline$\geq 710$ & $170.4(99.0-207.0)$ & & $29.2(6.3-101.1)$ & \\
\hline Interleukin-6 (pg/mL, median $[\mathrm{IQR}])(<7)$ & & 0.14 & & 0.91 \\
\hline$<7$ & $172.5(110.9-212.6)$ & & $30.6(8.8-91.1)$ & \\
\hline$\geq 7$ & $163.6(88.4-212.6)$ & & $30.4(7.3-99.8)$ & \\
\hline Interleukin-8 $(\mathrm{pg} / \mathrm{mL}$, median $[\mathrm{IQR}])(<62)$ & & 0.44 & & 0.17 \\
\hline$<62$ & $171.6(101.3-213.0)$ & & $30.3(8.5-94.0)$ & \\
\hline$\geq 62$ & $161.2(22.2-205.9)$ & & $17.7(2.4-111.2)$ & \\
\hline Interleukin-10 $(\mathrm{pg} / \mathrm{mL}$, median $[\mathrm{IQR}])(<9.1)$ & & 0.035 & & 0.63 \\
\hline$<9.1$ & $172.5(101.4-215.2)$ & & $28.4(8.0-91.2)$ & \\
\hline$\geq 9.1$ & $151.5(84.4-192.4)$ & & $35.4(5.1-131.1)$ & \\
\hline $\begin{array}{l}\text { Tumor necrosis factor alpha }(\mathrm{pg} / \mathrm{mL} \text {, median }[\mathrm{IQR}]) \\
(<8.1)\end{array}$ & & 0.20 & & 0.0069 \\
\hline$<8.1$ & $174.8(108.0-215.3)$ & & $35.8(12.2-98.8)$ & \\
\hline$\geq 8.1$ & $169.1(95.6-212.5)$ & & $25.5(5.2-85.6)$ & \\
\hline
\end{tabular}

${ }^{a}$ Calculated using the Mann-Whitney $U$ test or Kruskal-Wallis test 

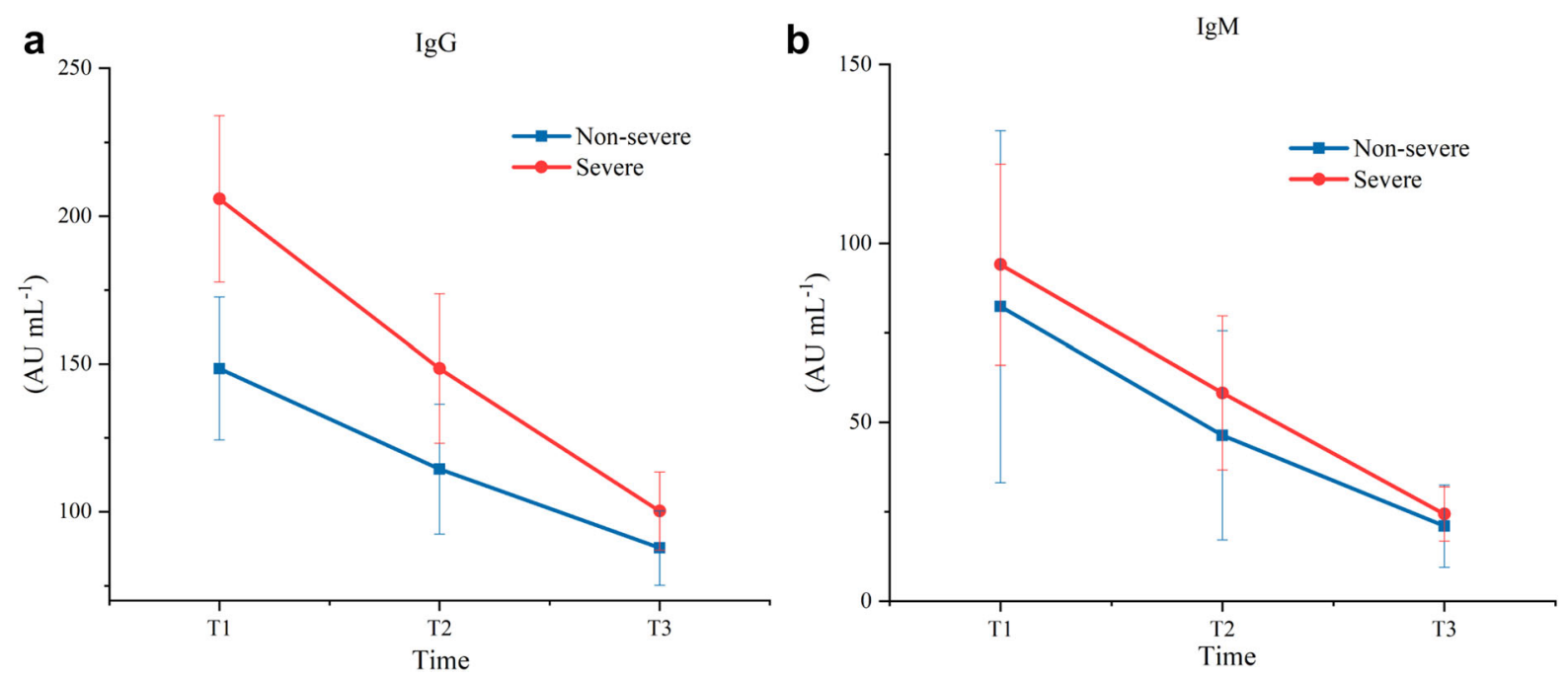

Fig. 3 Dynamic changes in antibody responses in selected patients during course of COVID-19. a IgG and b IgM

severe/non-severe groups were relatively similar at the different time points (Fig. 3).

Logistic regression was conducted to identify the correlation between the log-transformed level of IgG and progression of COVID-19. In the multivariate logistic regression, we included comorbidities, age, sex, interleukin-10, procalcitonin, and total bilirubin as potential cofactors, given that they appear to influence COVID-19 progression and show differential distribution among patients of different severity. After adjustment for cofactors, higher levels of IgG in the first 14 days from disease onset were independently associated with severe illness (odds ratio $[\mathrm{OR}]=1.368,95 \%$ confidence interval [CI] 1.138-1.645). However, this significant correlation did not hold after 15 days $(\mathrm{OR}=1.050,95 \%$ CI 0.859-1.284) (Table 3).

\section{DISCUSSION}

In most viral diseases, virus-specific IgM is usually the first positively identified antibody in the acute stage, followed by an increase in specific IgG at the later stage. However, this may differ in COVID-19. For example, Zhang et al. detected virus-specific IgM and IgG by enzymelinked immunoassay and identified more patients as IgG positive than IgM positive on the first sampling day and at day 5 [13]. Long et al. also reported the SARS-CoV-2-specific IgM

Table 3 Logistic regression analysis of $\operatorname{IgG}_{\text {level }}{ }^{\mathrm{a}}$ and disease severity

\begin{tabular}{lll}
\hline Sampling time from disease onset & OR $(\mathbf{9 5 \%} \mathbf{C I})$ & \\
\cline { 2 - 3 } & Crude $^{\mathbf{b}}$ & Model 1 $^{\mathbf{c}}$ \\
\hline$\leq 14$ days & $1.359(1.188-1.555)^{*}$ & $1.368(1.138-1.645)^{*}$ \\
$\geq 15$ days & $0.955(0.829-1.101)$ & $1.050(0.859-1.284)$ \\
All & $1.113(1.012-1.224)^{*}$ & $1.194(1.044-1.365)^{*}$ \\
\hline
\end{tabular}

*Significant at $P<0.05$

${ }^{a} \log$ scale $\left(\log _{10}\right)$

b Crude: unadjusted

c Model 1: adjusted for sex, age, comorbidities, interleukin-10, procalcitonin, and total bilirubin 
antibody responses could be observed within 1 week from symptom onset, but high serum levels of IgG can also be detected at the same time or even earlier [14]. Notably, Jin et al. found that the positive rate of specific IgG was significantly higher than that of IgM during COVID-19 [15]. A similar phenomenon was observed in our study, with the positive rate of virus-specific IgG found to be significantly higher than that of virus-specific IgM in the first and second weeks. At present, existing mechanisms cannot explain this result. One possible reason for this phenomenon may be that unlike Middle East respiratory syndrome coronavirus (MERS-CoV) and SARS-CoV infections, in which the peak viral load in patients generally occurs $7-10$ days after disease onset $[16,17]$, patients with COVID-19 have higher viral loads at the time of disease onset, similar to that of influenza $[2,18]$. Previous research has also shown that levels of specific IgG against SARS-CoV-2 are correlated with virus neutralization titer [2]. In Helicobacter pylori infection, IgG antibodies against $H$. pylori are positively correlated with colonization density [19]. Although the underlying mechanisms related to strong IgG responses in early-stage COVID-19 are unclear, we suspect it may be related to high viral load.

Whether COVID-19 severity can impact specific antibody detection remains unclear. In a previous 23-case study, serum antibody levels were not correlated with clinical severity of COVID-19 [2]. However, Hou et al. observed that the levels of both specific IgG and IgM against SARS-CoV-2 differed significantly among 338 patients with different illness severity of COVID-19. In our research, we found sampling time from symptom onset to be an important factor when testing specific antibody levels. Previous studies have reported that 14 days after the disease onset might be a meaningful time point for specific antibody response during COVID-19 course, and a similar phenomenon was also observed in our analysis $[14,20,21]$. In the early stage of the disease, severe and non-severe patients may have distinct immune response efficiency. In the first 14 days of symptom onset, patients with severe illness had a significantly higher level of specific IgG against SARS-CoV-2 than non-severe patients. As age, sex, and comorbidities are associated with severe COVID-19 [22-24], we combined these cofactors in a multivariate analysis, which confirmed that a higher level of IgG was significantly associated with severe illness. However, this phenomenon became less obvious at 15 days from disease onset. Previous research has indicated that the detection of specific IgG antibodies against SARS-CoV-2 may play a significant role during the COVID-19 pandemic [25]. For SARS-CoV infected patients, researchers have found that a more robust IgG response is associated with severe illness [26], similar to our results reported here. Furthermore, over $90 \%$ of individuals with SARS-CoV-2 infection are IgG seropositive after 14 days of disease onset [14], as confirmed in our study. We found that the level of specific IgM in severe/non-severe patients also differed in the early stages of the disease, but this difference was not as obvious as that of IgG. After examining the serological results of asymptomatic patients, Long et al. found that, in the acute phase, specific IgG levels are significantly lower in asymptomatic than symptomatic patients [27], suggesting that the immune response may be related to disease severity.

The pro-inflammatory cytokines released by various immune cells can contribute to pathogenic inflammation and are related to COVID19 severity [28, 29]. We also observed differences in the levels of cytokines and other laboratory indicators that may be associated with specific antibodies against SARS-CoV-2.

Several study limitations should be noted. Serological antibody tests can vary in their sensitivity and specificity. Previous infection with other coronaviruses may confound results. In addition, specific antibody production can also be affected in potentially immunodeficient patients.

\section{CONCLUSIONS}

This study showed a potential positive correlation between a strong specific IgG response in the early stage of disease (within 14 days from disease onset) and COVID-19 severity, although 
further studies are needed to validate our conclusions.

\section{ACKNOWLEDGEMENTS}

We would like to show our great respect to all the workers and volunteers in the fight against COVID-19, especially to the medical workers who work with the authors on the frontline.

Funding. No sponsorship or funding was received for this study or publication of this article.

Authorship. All named authors meet the International Committee of Medical Journal Editors (ICMJE) criteria for authorship for this article, take responsibility for the integrity of the work as a whole, and have given their approval for this version to be published

Authorship Contributions. J.L. conceived and designed the study. W.L. and P.W. prepared this paper, L.H., Y.M., P.W., and W.D participated in the data collection and data management, W.L. and P.W. contributed to clinical analysis and the data analysis. The authors read and approved the final manuscript. Wanrong $\mathrm{Lu}$ and Ping $\mathrm{Wu}$ contributed equally to this work.

Disclosures. Wanrong $\mathrm{Lu}$, Ping $\mathrm{Wu}$, Liang $\mathrm{He}$, Yifan Meng, Peng Wu, Wencheng Ding and Jia Liu declare that they have no competing interests.

Compliance with Ethics Guidelines. All procedures were conducted in accordance with ethical standards in the 1964 Helsinki declaration and its later amendments or comparable ethical standards. The Ethical Committee of Tongji Hospital of Tongji Medical College at Huazhong University of Science and Technology approved this study. As the data were analyzed anonymously and retrospectively, written informed consent was not obtained.
Data Availability. The datasets analyzed in the current study are available from the corresponding author on reasonable request.

Open Access. This article is licensed under a Creative Commons Attribution-NonCommercial 4.0 International License, which permits any non-commercial use, sharing, adaptation, distribution and reproduction in any medium or format, as long as you give appropriate credit to the original author(s) and the source, provide a link to the Creative Commons licence, and indicate if changes were made. The images or other third party material in this article are included in the article's Creative Commons licence, unless indicated otherwise in a credit line to the material. If material is not included in the article's Creative Commons licence and your intended use is not permitted by statutory regulation or exceeds the permitted use, you will need to obtain permission directly from the copyright holder. To view a copy of this licence, visit http://creativecommons.org/licenses/by$\mathrm{nc} / 4.0 /$.

\section{REFERENCES}

1. Azkur AK, Akdis M, Azkur D, et al. Immune response to SARS-CoV-2 and mechanisms of immunopathological changes in COVID-19. Allergy. 2020;75:1564-81.

2. To KK, Tsang OT, Leung WS, et al. Temporal profiles of viral load in posterior oropharyngeal saliva samples and serum antibody responses during infection by SARS-CoV-2: an observational cohort study. Lancet Infect Dis. 2020;20(5):565-74.

3. Zeng $\mathrm{H}, \mathrm{Xu} \mathrm{C}$, Fan J, et al. Antibodies in infants born to mothers with COVID-19 pneumonia. JAMA. 2020;323:1848-9.

4. Wu Z, McGoogan JM. Characteristics of and important lessons from the coronavirus disease 2019 (COVID-19) outbreak in China: summary of a report of 72314 cases from the Chinese Center for Disease Control and Prevention. JAMA. 2020;323: 1239-42.

5. WHO. Report of the WHO-China Joint Mission on coronavirus disease 2019 (COVID-19). https://www. who.int/docs/default-source/coronaviruse/whochina-joint-mission-on-covid-19-final-report. 
6. Qin C, Zhou L, Hu Z, et al. Dysregulation of immune response in patients with COVID-19 in Wuhan, China. Clin Infect Dis. 2020;71:762-8.

7. He R, Lu Z, Zhang L, et al. The clinical course and its correlated immune status in COVID-19 pneumonia. J Clin Virol. 2020;127:104361.

8. Phipps WS, SoRelle JA, Li QZ, et al. SARS-CoV-2 antibody responses do not predict COVID-19 disease severity. Am J Clin Pathol. 2020;154:459-65.

9. Liu X, Zheng X, Liu B, et al. Serum IgM against SARS-CoV-2 correlates with in-hospital mortality in severe/critical patients with COVID-19 in Wuhan, China. Aging (Albany NY). 2020;12:12432-40.

10. Chen $\mathrm{T}, \mathrm{Wu} \mathrm{D}$, Chen $\mathrm{H}$, et al. Clinical characteristics of 113 deceased patients with coronavirus disease 2019: retrospective study. BMJ. 2020;368: $\mathrm{m} 1091$.

11. Grein J, Ohmagari N, Shin D, et al. Compassionate use of remdesivir for patients with severe COVID19. N Engl J Med. 2020;382(24):2327-36.

12. Hou H, Wang T, Zhang B, et al. Detection of IgM and IgG antibodies in patients with coronavirus disease 2019. Clin Transl Immunol. 2020;9(5): e01136.

13. Zhang W, Du RH, Li B, et al. Molecular and serological investigation of 2019-nCoV infected patients: implication of multiple shedding routes. Emerg Microbes Infect. 2020;9(1):386-9.

14. Long QX, Liu BZ, Deng HJ, et al. Antibody responses to SARS-CoV-2 in patients with COVID-19. Nat Med. 2020;26(6):845-8.

15. Jin Y, Wang M, Zuo Z, et al. Diagnostic value and dynamic variance of serum antibody in coronavirus disease 2019. Int J Infect Dis. 2020;94:49-52.

16. Chan JF, Lau SK, To KK, Cheng VC, Woo PC, Yuen $\mathrm{KY}$. Middle East respiratory syndrome coronavirus: another zoonotic betacoronavirus causing SARSlike disease. Clin Microbiol Rev. 2015;28(2): 465-522.

17. Peiris JS, Chu CM, Cheng VC, et al. Clinical progression and viral load in a community outbreak of coronavirus-associated SARS pneumonia: a prospective study. Lancet. 2003;361(9371): 1767-72.

18. Hayden FG, Treanor JJ, Fritz RS, et al. Use of the oral neuraminidase inhibitor oseltamivir in experimental human influenza: randomized controlled trials for prevention and treatment. JAMA. 1999;282(13):1240-6.

19. Kreuning J, Lindeman J, Biemond I, Lamers CB. Relation between IgG and IgA antibody titres against Helicobacter pylori in serum and severity of gastritis in asymptomatic subjects. J Clin Pathol. 1994;47(3):227-31.

20. Young BE, Ong SWX, Ng LFP, et al. Viral dynamics and immune correlates of COVID-19 disease severity. Clin Infect Dis. 2020. https://doi.org/10.1093/ cid/ciaa1280.

21. Zhou S, Wang Y, Zhu T, Xia L. CT features of coronavirus disease 2019 (COVID-19) pneumonia in 62 patients in Wuhan, China. Am J Roentgenol. 2020;214(6):1287-94.

22. Zhou F, Yu T, Du R, et al. Clinical course and risk factors for mortality of adult inpatients with COVID-19 in Wuhan, China: a retrospective cohort study. Lancet. 2020;395(10229):1054-62.

23. Guan WJ, Liang WH, Zhao Y, et al. Comorbidity and its impact on 1590 patients with COVID-19 in China: a nationwide analysis. Eur Respir J. 2020;55(5):2000547.

24. Zhang X, Tan Y, Ling Y, et al. Viral and host factors related to the clinical outcome of COVID-19. Nature. 2020;583:437-40.

25. Theel ES, Slev P, Wheeler S, Couturier MR, Wong SJ, Kadkhoda K. The role of antibody testing for SARSCoV-2: is there one? J Clin Microbiol. 2020;58: e00797.

26. Lee N, Chan PK, Ip M, et al. Anti-SARS-CoV IgG response in relation to disease severity of severe acute respiratory syndrome. J Clin Virol. 2006;35(2):179-84.

27. Long QX, Tang XJ, Shi QL, et al. Clinical and immunological assessment of asymptomatic SARSCoV-2 infections. Nat Med. 2020;26:1200-4.

28. Deftereos SG, Siasos G, Giannopoulos G, et al. The Greek study in the effects of colchicine in COvid-19 complications prevention (GRECCO-19 study): rationale and study design. Hellenic $\mathrm{J}$ Cardiol. 2020;61:42-5.

29. Shneider A, Kudriavtsev A, Vakhrusheva A. Can melatonin reduce the severity of COVID-19 pandemic? Int Rev Immunol. 2020;39:1-10. 